\title{
Systematic analysis of the achaete-scute complex-like gene signature in clinical cancer patients
}

\author{
CHIH-YANG WANG ${ }^{1-3}$, PAYAM SHAHI ${ }^{4}$, JOHN TING WEI HUANG ${ }^{5}$, NAM NHUT PHAN ${ }^{6,7}$, \\ ZHENGDA SUN ${ }^{8}$, YEN-CHANG LIN ${ }^{7}$, MING-DERG LAI ${ }^{2,3}$ and ZENA WERB ${ }^{1}$
}

\author{
${ }^{1}$ Department of Anatomy, University of California, San Francisco, CA 94143, USA; ${ }^{2}$ Department of Biochemistry \\ and Molecular Biology; ${ }^{3}$ Institute of Basic Medical Sciences, College of Medicine, National Cheng Kung University, \\ Tainan, Taiwan 11114, R.O.C.; Departments of ${ }^{4}$ Bioengineering and Therapeutic Sciences, and ${ }^{5}$ Oncology, University \\ of California, San Francisco, CA 94143, USA; ${ }^{6}$ Faculty of Applied Sciences, Ton Duc Thang University, Ho Chi Minh 7000, \\ Vietnam; ${ }^{7}$ Graduate Institute of Biotechnology, Chinese Culture University, Taipei, Taiwan 11114, \\ R.O.C.; ${ }^{8}$ Department of Radiology, University of California, San Francisco, CA 94143, USA
}

Received May 6, 2016; Accepted September 23, 2016

DOI: $10.3892 / \operatorname{mco} .2016 .1094$

\begin{abstract}
The achaete-scute complex-like (ASCL) family, also referred to as 'achaete-scute complex homolog' or 'achaete-scute family basic helix-loop-helix transcription factor', is critical for proper development of the nervous system and deregulation of ASCL plays a key role in psychiatric and neurological disorders. The ASCL family consists of five members, namely ASCL1, ASCL2, ASCL3, ASCL4 and ASCL5. The ASCL1 gene serves as a potential oncogene during lung cancer development. There is a correlation between increased ASCL2 expression and colon cancer development. Inhibition of ASCL2 reduced cellular proliferation and tumor growth in xenograft tumor experiments. Although previous studies demonstrated involvement of ASCL1 and ASCL2 in tumor development, little is known on the remaining ASCL family members and their potential effect on tumorigenesis. Therefore, a holistic approach to investigating the expression of ASCL family genes in diverse types of cancer may provide new insights in cancer research. In this study, we utilized a web-based microarray database (Oncomine; www.oncomine.org) to analyze the transcriptional expression of the ASCL family in clinical cancer and normal tissues. Our bioinformatics analysis revealed the
\end{abstract}

Correspondence to: Dr Ming-Derg Lai, Department of Biochemistry and Molecular Biology, College of Medicine, National Cheng Kung University, 1 University Road, Tainan, Taiwan 11114, R.O.C.

E-mail: a1211207@mail.ncku.edu.tw

Dr Zena Werb, Department of Anatomy, University of California, 513 Parnassus Ave, San Francisco, CA 94143, USA

E-mail: zena.werb@ucsf.edu

Key words: achaete-scute complex-like, ASCL1, ASCL2, ASCL3, ASCL4, ASCL5, cancer potential involvement of multiple ASCL family members during tumor onset and progression in multiple types of cancer. Compared to normal tissue, ASCL1 exhibited a higher expression in cancers of the lung, pancreas, kidney, esophagus and head and neck, whereas ASCL2 exhibited a high expression in cancers of the breast, colon, stomach, lung, head and neck, ovary and testis. ASCL3, however, exhibited a high expression only in breast cancer. Interestingly, ASCL1 expression was downregulated in melanoma and in cancers of the bladder, breast, stomach and colon. ASCL2 exhibited low expression levels in sarcoma, melanoma, brain and prostate cancers. Reduction in the expression of ASCL3 was detected in lymphoma, bladder, cervical, kidney and epithelial cancers. Similarly, ASCL5 exhibited low expression in the majority of brain cancer subtypes, such as glioblastoma and oligodendroglioma. This analysis supports the hypothesis that specific ASCL members may play an important role in cancer development. Collectively, our data suggest that alterations in the expression of ASCL gene family members are correlated with cancer development. Furthermore, ASCL family members were categorized according to cancer subtype. The aim of this report was to provide novel insights to the significance of the ASCL family in various cancers and our findings suggested that the ASCL gene family may be an ideal target for future cancer studies.

\section{Introduction}

Cancer is the leading cause of morbidity and mortality worldwide according to the data of the International Agency for Research on Cancer (https://www.iarc.fr/), updated February, 2015. In 2012, there were an estimated 14 million new cancer cases and 8.2 million cancer-related deaths (1). Multiple studies indicate that the most prevalent cancers are lung (1.59 million deaths), liver (745,000 deaths), stomach (723,000 deaths), colorectal (694,000 deaths), breast (521,000 deaths) and esophageal cancer (400,000 deaths) (1). Since aberrations in the transcriptional expression are known to cause cancer, a 
primary approach to understanding cancer is to identify oncogenic genes and elucidate their roles in cancer regulation (2).

The achaete-scute complex-like (ASCL) gene family, also referred toas 'achaete-scute complex homolog' or 'achaete-scute family basic helix-loop-helix transcription factor' and mammalian achaete-scute homologues (MASH), comprises five family members (ASCL1-ASCL5; Table I) (3,4). All ASCL genes encode basic helix-loop-helix transcription factors that control the development of the nervous system $(2,3)$. Given the involvement of ASCL in neuroblast cell fate determination, the ASCL family members are also referred to as proneural genes. The function of the ASCL gene family is highly conserved across all vertebrates; however, ASCL family gene expression and their effect on target cells are not restricted to the nervous system. For example, expression of ASCL family members is detected in progenitor cells during muscle and gut cell differentiation (5-7). These findings emphasize the significance of ASCL genes during organogenesis. However, whether ASCL family members play an integral role in cancer initiation and progression has not been fully elucidated.

ASCL1 is briefly expressed during nervous system development, including olfactory and autonomic neural development (3). ASCL1 is also detected in sympathetic neurons during early embryonic stages in humans (4). In addition to its role during development, ASCL1 overexpression has been associated with human neuroendocrine cancers. However, whether ASCL1 plays a role in the initiation and progression of other cancers remains unclear $(8,9)$.

ASCL2 (HASH2) is expressed by trophoblasts during placental development (10). Recent data suggest that ASCL2 may affect the Wnt signaling pathway. The ASCL2 may form a complex with the Wnt pathway signal transducer $\beta$-catenin in order to synergistically activate the expression of downstream target genes $(11,12)$. Moreover, ASCL2 may modulate the plasticity between epithelial and mesenchymal characteristics in colon cancer (13).

Little is known on the function of the remaining ASCL family members. ASCL3 is expressed in adult progenitor cells that mature into acinar- and duct-type cells in murine salivary glands (14). ASCL4 may play a role during skin development and it exhibits a 7-fold higher expression levels in fetal skin compared with adult skin (15). At present, the mechanism and function of ASCL5 are yet to be determined. Although previous studies describe a developmentally significant role for the ASCL gene family, our overall understanding of their function during development and their potential roles during tumorigenesis is incomplete.

Major strives have been made to catalog the mRNA expression profiles of numerous cancers in vast databases. One advantage of these massive resources is to increase our ability to identify potential biomarkers in specific tumors and to characterize their molecular signatures. Since tumor initiation coincides with alterations in normal gene expression, analysis of the differential gene expression in tumor cells may reveal unique tumor biomarkers. Thus, these databases, particularly the Oncomine microarray database (16), were utilized to gain a better understanding of the ASCL family role in the initiation and progression of several tumors, aiming to provide useful insights in prospective research into cancer association with the ASCL gene family.

\section{Materials and methods}

Meta-analysis. A meta-analysis was used to analyze the mRNA expression of the ASCL family in clinical cancer specimens by following the PRISMA guidelines $(17,18)$ Oncomine (www. oncomine.org), a web-based microarray database, was used to analyze the mRNA expression of ASCL in clinical cancer tissue (19). According to 'Oncomine Platform Overview Q1 2014,' the database resource of Oncomine includes upwards of 700 independent datasets with an estimated 90,000 microarray trials. Oncomine has standardized and organized the datasets of public cancer microarray data into different cancer type and subtypes $(16,20)$.

ASCL gene expression. ASCL gene (ASCL1-5) expression in 20 cancer types was investigated. Detailed information on ASCL genes, such as tissue of origin, comparing mRNA expression with matched normal tissue types, was displayed in groups. The gene summary view in Oncomine was presented throughout the analysis with an alteration in color, reflecting the degree of expression. The expression coloration represents a gene with highest ranking in a particular type of cancer based on the threshold analysis (Fig. 1).

Statistical analysis. The cancer vs. normal filter that only displayed datasets investigating ASCL gene mRNA expression in the same tissue of origin was selected. To be included in the study, all the data had to satisfy the threshold with a $\mathrm{P}$-value of $<0.01$, a fold change of $>1.5$ and a gene rank percentile of $<10 \%$. Statistical analyses were performed using the Oncomine default algorithms, such as P-values, two-tailed Student's $t$-test, and multiple testing corrections.

\section{Results and Discussion}

Analysis of ASCL expression in various tumors. Several studies have identified potential roles for ASCL family members in cancer development; however, our overall understanding of ASCL family member function during tumor initiation and progression is incomplete. To investigate a potential alteration in ASCL family gene expression in different types of cancer, we accessed the web-based Oncomine microarray database to analyze 20 different types of cancer. Cancer tissue was compared with normal tissue (control) and thresholds were set to screen suitable datasets from the Oncomine database. To include suitable datasets for further analysis, the gene expression in cancer cells compared with that of normal tissue had to fulfill the following threshold criteria: Fold change $>1.5, \mathrm{P}<0.01$ and gene rank percentile $<10 \%$ (Fig. 1). Our analysis demonstrated alterations in ASCL gene family expression in multiple cancer types, which may provide useful information for future studies investigating the role of ASCL genes in tumorigenesis.

ASCL1. The proneural transcriptional factor ASCL1/MASH1 is essential for proper nervous system development (21). In the cerebrum, ASCL1 controls the primitive as well as the late phases of neurogenesis, with the division of radial glia progenitors and the radial migration of post-mitotic neurons $(22,23)$. ASCL1 controls the expression of numerous target genes that are involved in cell cycle progression and cytoskeletal 
Table I. Function of the achaete-scute complex-like family members.

\begin{tabular}{|c|c|c|c|}
\hline Official symbol & Alias & Biological function & (Refs.) \\
\hline \multirow[t]{9}{*}{ ASCL1 } & \multirow{9}{*}{$\begin{array}{l}\text { ASH1, } \\
\text { HASH1, } \\
\text { MASH1, } \\
\text { bHLHa46 }\end{array}$} & Regulation of transcription from RNA polymerase II promoter & $(37)$ \\
\hline & & Cerebral cortex GABAergic interneuron differentiation & $(38)$ \\
\hline & & Sympathetic nervous system development & $(39)$ \\
\hline & & Negative regulation of apoptotic process & $(40)$ \\
\hline & & Noradrenergic neuron fate commitment & $(41)$ \\
\hline & & Lung epithelial cell differentiation & $(42)$ \\
\hline & & Notch signaling pathway & $(43)$ \\
\hline & & Response to retinoic acid & $(37)$ \\
\hline & & Neurogenesis & $(44)$ \\
\hline \multirow[t]{7}{*}{ ASCL2 } & \multirow[t]{2}{*}{ ASH2, } & Regulation of transcription from RNA polymerase II promoter & $(45,46)$ \\
\hline & & Spongiotrophoblast differentiation & $(47)$ \\
\hline & \multirow[t]{2}{*}{ HASH2, } & In utero embryonic development & $(10)$ \\
\hline & & Sequence-specific DNA binding & $(45)$ \\
\hline & \multirow[t]{2}{*}{ MASH2, } & Somatic stem cell maintenance & (9) \\
\hline & & Placenta development & $(48)$ \\
\hline & bHLHa45 & & \\
\hline \multirow[t]{3}{*}{ ASCL3 } & \multirow[t]{2}{*}{ SGN1, } & RNA polymerase II regulatory region sequence-specific DNA binding & $(49)$ \\
\hline & & Regulation of transcription from RNA polymerase II promoter & $(49)$ \\
\hline & $\begin{array}{l}\text { HASH3, } \\
\text { bHLHa42 }\end{array}$ & Transcription factor complex & $(49)$ \\
\hline \multirow[t]{3}{*}{ ASCL4 } & \multirow[t]{2}{*}{ HASH4, } & Regulation of transcription from RNA polymerase II promoter & $(15)$ \\
\hline & & Skin development & $(15)$ \\
\hline & bHLHa44 & Protein binding & $(50)$ \\
\hline ASCL5 & bHLHa47 & Regulation of transcription, DNA-template & $(33)$ \\
\hline
\end{tabular}

ASCL, achaete-scute complex-like; bHLH, basic helix-loop-helix.

reorganization associated with neuronal cell migration $(6,7)$. Recently, a potential oncogenic role for ASCL1 in lung cancer has been reported (23); however, the role of ASCL1 in cancer remains unclear. Our analysis indicated that ASCL1 is significantly overexpressed in the majority of cancer types, such as cancers of the brain, lung, head and neck, prostate, pancreas, kidney, esophagus, leukemia, lymphoma and sarcoma (Fig. 1). ASCL1 also ranked in the top $1 \%$ of overexpressed genes in leukemia, brain and lung cancer. Importantly, our analysis indicated that ASCL1 is overexpressed in the majority of brain cancers, such as glioblastoma, oligodendroglioma, anaplastic astrocytoma, anaplastic oligodendroglioma and anaplastic oligoastrocytoma. Compared with normal tissue, ASCL1 exhibited a higher expression in brain tumor tissues (P-values of 0.004-2.50E-21), and the ASCL1 gene ranked 1-7\% in our meta-analysis results (Table II). We found that, in various lung cancers, such as small-cell lung carcinoma and carcinoid tumors, ASCL1 was significantly overexpressed (P-values of $0.002-3.53 \mathrm{E}-13)$ and the gene ranked in the top $1-8 \%$ relative to the control. In addition to brain tumors, ASCL1 was also highly expressed in acute adult T-cell leukemia/lymphoma, with the gene ranking in the top 1\%, a 3.76-fold change, and a $\mathrm{P}=3.43 \mathrm{E}-5$. These data indicated that ASCL1 expression varied in different types of leukemia. We also observed that ASCL1 was highly expressed in leiomyosarcoma (3.55-fold change, $\mathrm{P}=6.13 \mathrm{E}-4$ and gene ranking in the top $7 \%$ ), prostate carcinoma (3.21-fold change, $\mathrm{P}=0.001$ and gene ranking in the top $1 \%$ ), pancreatic adenocarcinoma (3.22-fold change, $\mathrm{P}=0.002$ and gene ranking in the top $6 \%$ ), renal oncocytoma (5.16-fold change, $\mathrm{P}=0.002$ and gene ranking in the top $8 \%$ ) and Barrett's esophagus (1.95-fold change, $\mathrm{P}=0.002$ and gene ranking in the top 9\%) (Table II).

In contrast to brain cancer and lymphomas, other cancers exhibited a reduction in ASCL1 expression. Gastric cancer and melanoma were among the top $1 \%$ of tumors that exhibited ASCL downregulation. The reduction in the ASCL1 transcript level suggested a tumor suppressor role, since tumor suppressor genes tend to exhibit a low or reduced expression in tumor tissue compared with normal tissue. Our analysis indicated lower ASCL1 expression in gastric, bladder and lung cancers. Evidence of this trend is also supported by a previous study that specifically evaluated a tumor suppressor gene in breast cancer datasets from the Oncomine database, which revealed a significant downregulation and low expression of the tumor suppressor gene ADAMTS1 in breast carcinomas when compared with normal tissue (24). Another similar study on the SIRT3 tumor suppressor gene also revealed lower expression in various tumor types (25). Given the pattern of downregulation, we hypothesized that ASCL1 may also play a tumor suppressor role in a subset of tissues. ASCL1 expression was considerably downregulated in lymphoma (diffuse large B-cell lymphoma, primary effusion lymphoma and mantle cell 
ASCL1 ASCL2 ASCL3 ASCL4 ASCL5
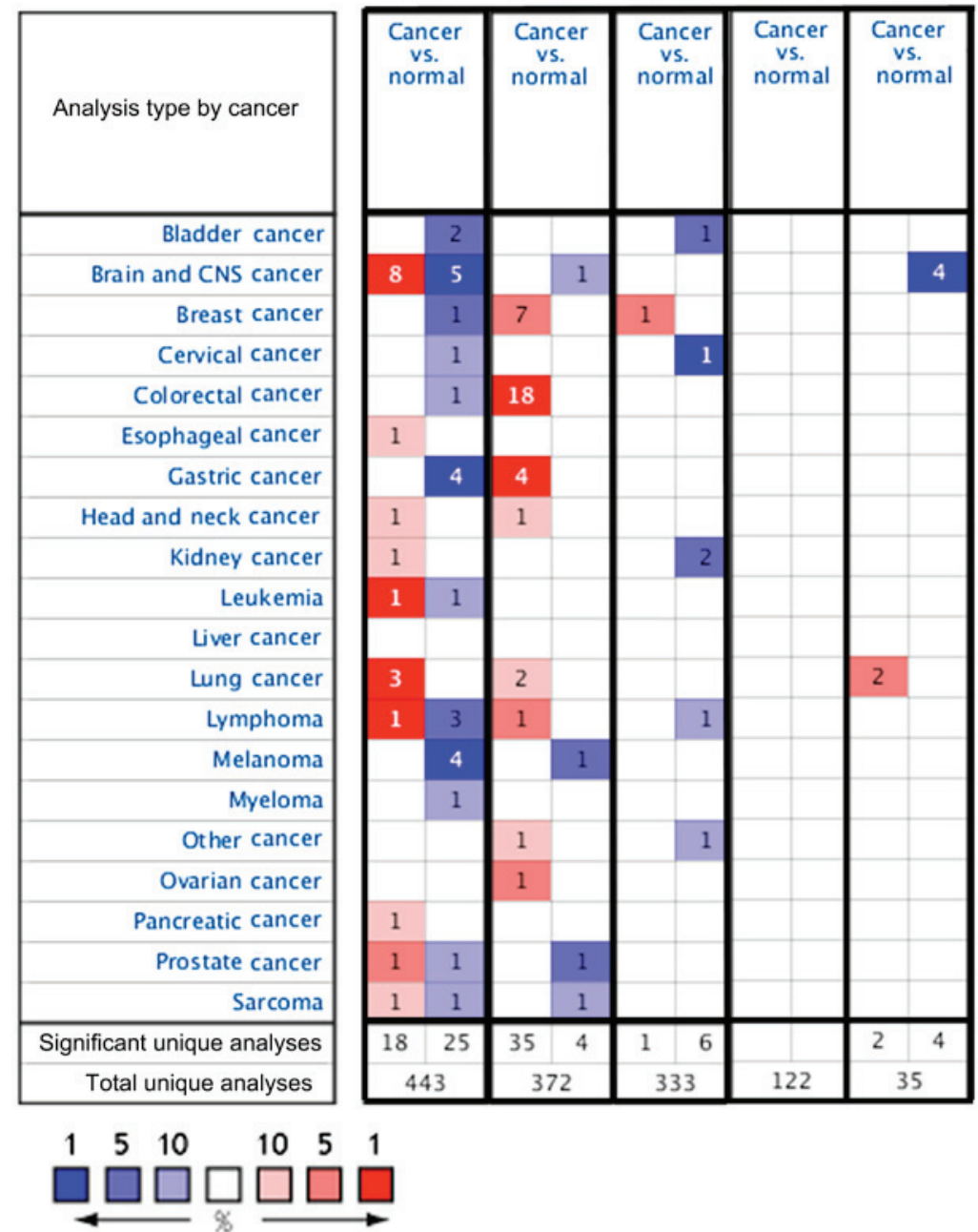

Figure 1. Expression of ASCL family genes in 21 types of cancer compared with normal tissue controls. The gene name of each channel is shown. Each gene was found in the tissue of origin, and the color gradient correlates with decreasing gene rank percentile. The search criteria threshold was set at $\mathrm{P}<0.01$ with a fold change of $>1.5$ and a gene rank percentile of $<10 \%$ for screening microarray datasets of cancer vs. normal cases. Cell color is determined by the best gene rank percentile for the analyses within the cell. Note: An analysis may be counted in more than one cancer type. ASCL, achaete-scute complex-like; CNS, central nervous system.

lymphoma). The reduction in ASCL1 expression ranged from -1.61- to -2.08-fold change, with P-values of 9.25E-4-1.15E-6 and the gene ranking in the top $3-10 \%$. Our bioinformatics analyses of gastric cancer revealed that ASCL1 exhibited a lower expression in the majority of gastric cancer subtypes, namely gastric mixed adenocarcinoma, gastrointestinal stromal tumors and gastric intestinal-type adenocarcinoma. The ASCL1 expression ranged from -1.60- to -3.64-fold downregulation, with P-values of 0.002-1.06E-6 and the gene ranking in the top 1-8\%. ASCL1 exhibited a lower expression in most types of melanoma, namely cutaneous melanoma, non-neoplastic nevus, benign melanocytic skin nevus and monoclonal gammopathy of undetermined significance. The ASCL1 transcript expression ranged from -1.64- to -3.22-fold downregulation, with P-values of 0.003-2.27E-5 and the gene ranking in the top 1-10\%. ASCL1 also exhibited a lower expression in bladder cancer (-1.77-fold change, $\mathrm{P}=2.36 \mathrm{E}-6$ and gene ranking in the top 6\%), invasive ductal breast carcinoma (-1.59-fold change, $\mathrm{P}=5.03 \mathrm{E}-6$ and gene ranking in the top $3 \%$ ) and colon cancer (-3.58-fold change, $\mathrm{P}=9.57 \mathrm{E}-6$ and gene ranking in the top 7\%) (Table II). These analyses suggest that the effect of ASCL1 downregulation on transcript expression may be an equally important alteration as increased expression in cancer biology. Interestingly, ASCL1 was found to be both up- and downregulated in brain tumors compared with normal tissue. The conflicting expression profiles of ASCL1 in the same type of cancer may be due to the wide-ranging categories for each of the cancer subtypes (Table II). This discrepancy may be a sample size issue arising from the original publications' reported data including a low number of samples from these tumor types. Collectively, our data suggest that alterations in ASCL1 expression may adversely affect tissue homeostasis, which may result in tumorigenesis.

ASCL2. ASCL2 is a basic helix-loop-helix transcription factor that is expressed in neuronal precursors (26). ASCL2 is a target of the Wnt signaling pathway and previous studies indicated that ASCL2 may regulate LGR5 in intestinal stem cells in response to Wnt signaling (9,27). Moreover, ASCL2 is involved in T-helper cell (TH) 1 and TH17 differentiation (28).

ASCL2 is strongly expressed in colon cancer tissues and cell lines (HT-29 and LS174T cells). Selective blockade of 


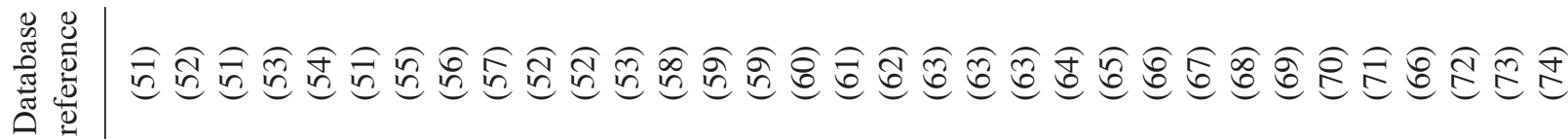

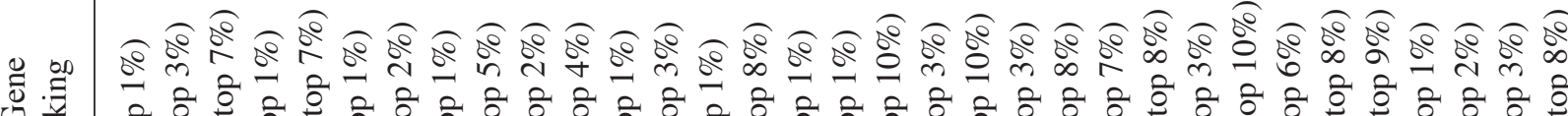

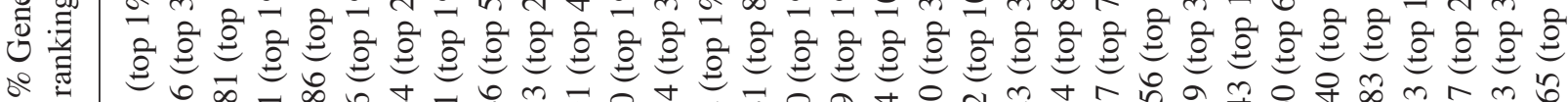

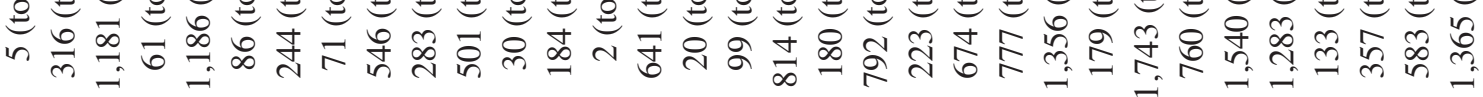

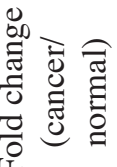

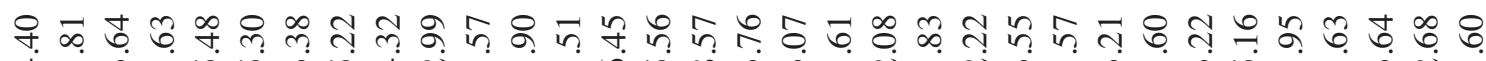

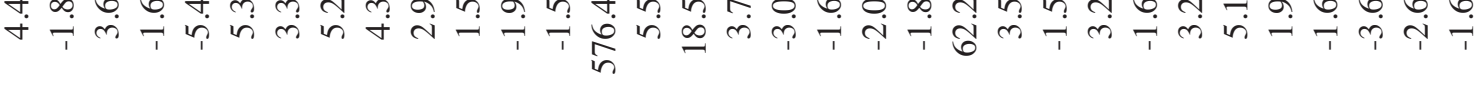

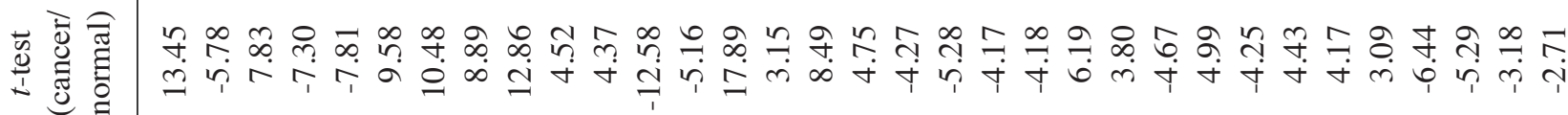

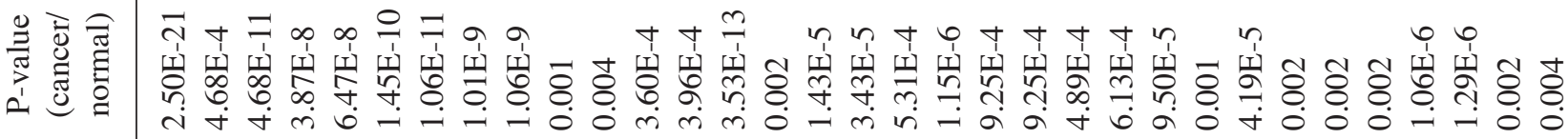

\&

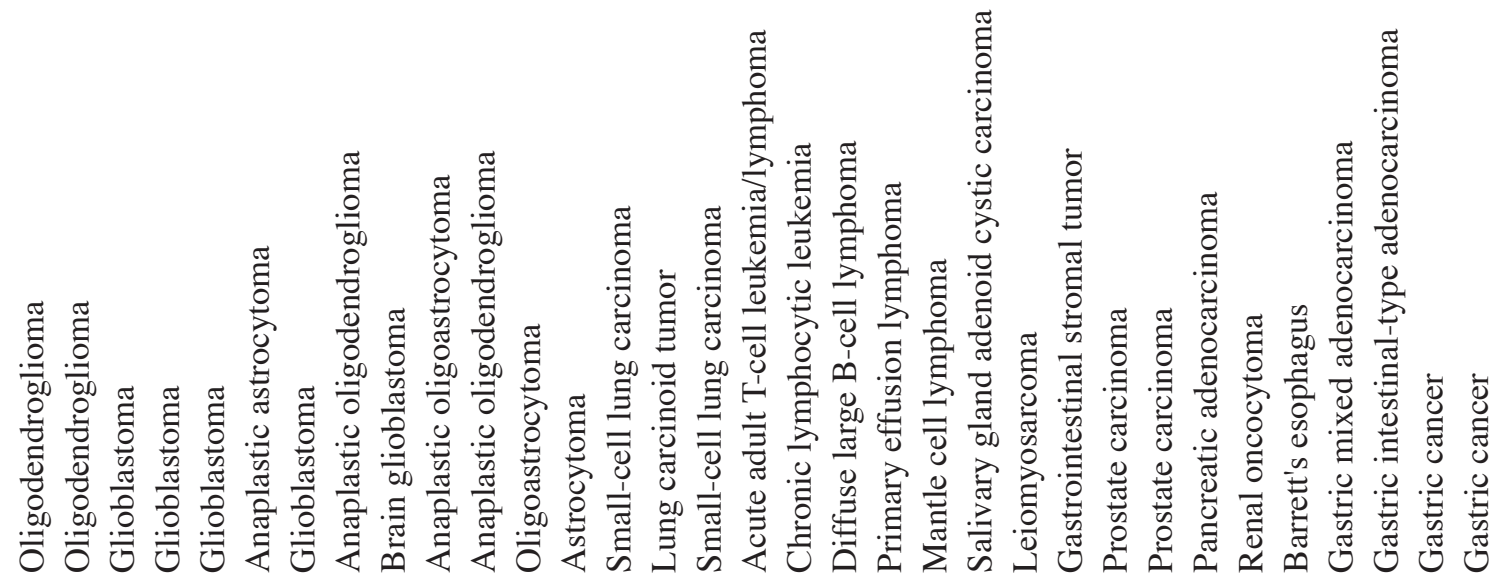

芯

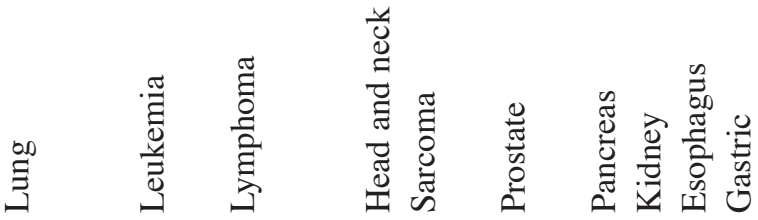


ASCL2 disrupts tumor cell proliferation and migration in tumor xenograft models $(10,29,30)$, a result consistent with our bioinformatics analysis (Fig. 1). This is particularly true in colon cancer tissues compared with normal tissues; however, whether ASCL2 plays a role in initiation and progression of other tumor types remains unclear.

ASCL2 expression was altered in 8 of 21 investigated cancers and was commonly observed in colorectal, gastric, breast, ovarian, testicular, lung and head and neck cancers, as well as lymphoma (Fig. 1). However, based on our bioinformatics analysis, our results were strikingly different. Downregulation of ASCL2 was only observed in the top 5\% and $9 \%$ of underexpressed genes in melanoma, and brain and gastric cancers, respectively (Fig. 1).

Our analysis revealed that ASCL2 expression is significantly upregulated in various breast cancer subtypes, such as invasive ductal, invasive lobular and medullary breast carcinoma, with P-values of 0.009-4.39E-72, gene ranking 2-10\% and a fold change of 1.66-14.9 compared with normal tissues (Table III). In colorectal tumors, such as adenocarcinoma of the colon, rectum, cecum or rectosigmoid region, colonic adenoma, rectal adenoma, colon adenoma epithelia and colon carcinoma epithelia, ASCL2 also exhibited significant upregulation compared with normal tissues, with P-values of 3.60E-7-8.24E-52, gene ranking 1-9\% and a fold change of 5.64-31.35 (Table III).

In gastric cancers, such as diffuse gastric adenocarcinoma, gastric intestinal-type adenocarcinoma and gastric mixed adenocarcinoma, ASCL2 exhibited significant upregulation compared with normal tissues, with P-values of 6.30E-4-1.74E-6, gene ranking $1-5 \%$ and a fold change of 2.35-4.45. Additionally, we found that ASCL2 is highly expressed in squamous cell lung carcinoma (1.84-fold change, $\mathrm{P}=7.81 \mathrm{E}-8$ and gene ranking in the top 9\%), nodular lymphocyte-predominant Hodgkin's lymphoma (2.65-fold change, $\mathrm{P}=7.61 \mathrm{E}-5$ and gene ranking in the top 5\%), nasopharyngeal carcinoma (1.56-fold change, $\mathrm{P}=5.08 \mathrm{E}-4$ and gene ranking in the top $10 \%$ ), ovarian endometrioid adenocarcinoma (1.76-fold change, $\mathrm{P}=0.001$ and gene ranking in the top 3\%); testicular seminoma (3.21-fold change, $\mathrm{P}=0.007$ and gene ranking in the top 6\%) (Table III).

Of note, lower ASCL2 gene expression levels were found in certain cancer subtypes, such as brain and gastric cancer, and melanoma. These subtypes included oligodendroglioma (-1.73-fold change, $\mathrm{P}=4.42 \mathrm{E}-4$ and gene ranking in the top 9\%), gastrointestinal stromal tumors (-2.59-fold change, $\mathrm{P}=4.59 \mathrm{E}-4$ and gene ranking in the top 9\%), and cutaneous melanoma (-6.74-fold change, $\mathrm{P}=6.22 \mathrm{E}-4$ and gene ranking in the top $5 \%$ ) (Table III). Thus, ASCL2 exhibited increased mRNA expression in some cancer tissues and decreased expression in others. Overall, our analysis indicated that ASCL2 was ranked in the top $10 \%$ of genes involved in the regulation of breast, colorectal, lung, gastric, head-neck, ovarian and testicular cancers and lymphoma, whereas in brain cancer and melanoma it exhibited significant downregulation compared with normal tissue (Table III). These findings indicate that cell context-specific alterations in ASCL2 expression may play a critical role in cancer biology.

ASCL3. ASCL3 (Sgn1) belongs to the MASH gene family of transcription factors that has been associated with cell fate 


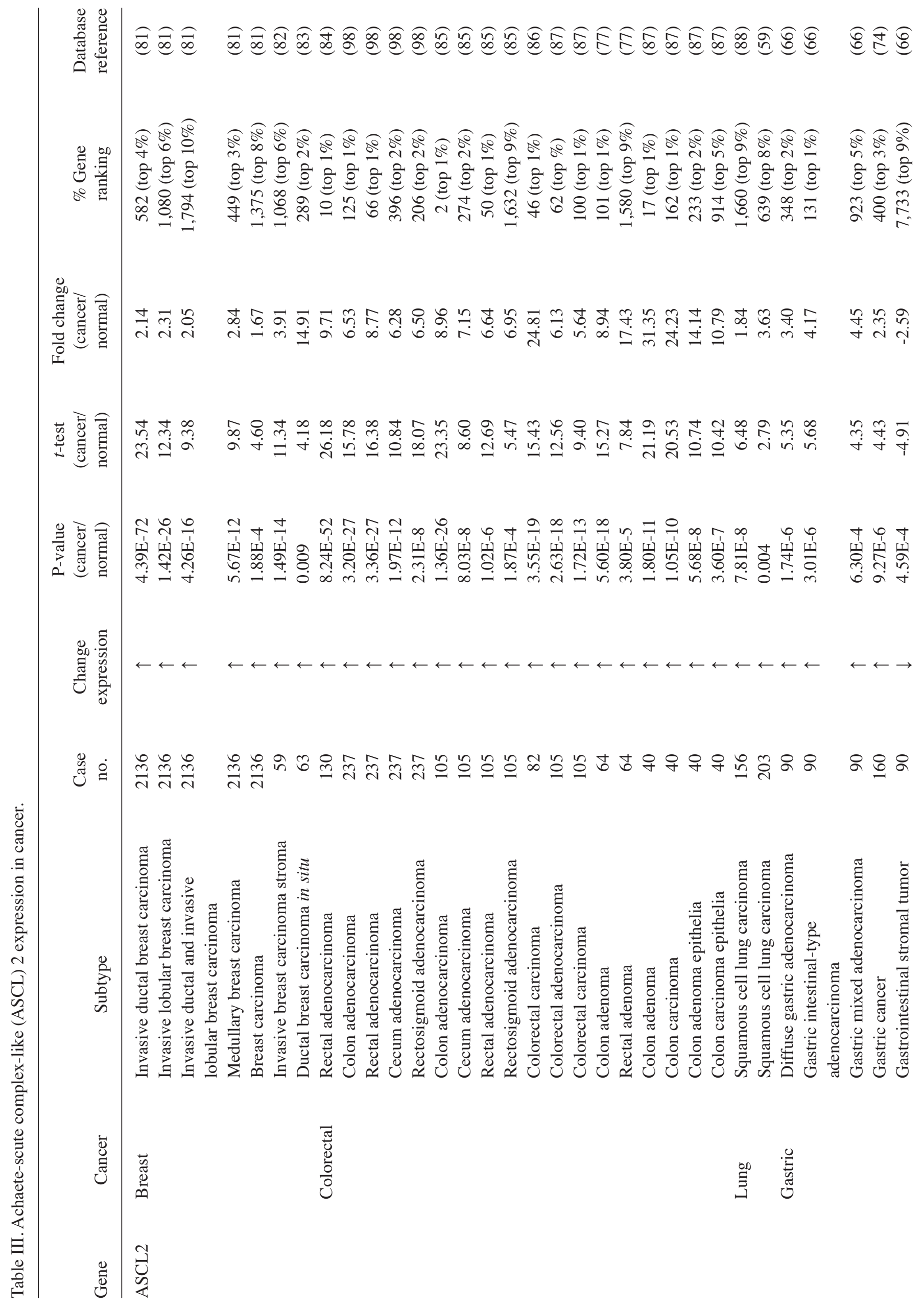




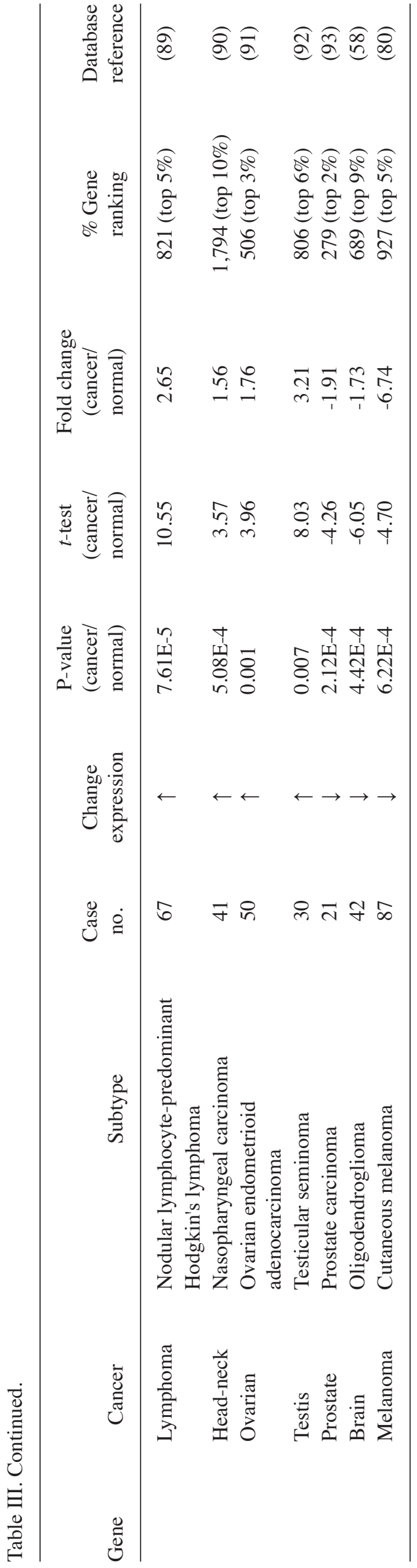

determination and contributes to the maintenance of the adult salivary gland homeostasis $(11,31)$. Our database analysis indicated that ASCL3 was highly expressed in invasive ductal breast carcinoma (2.26-fold change, $\mathrm{P}=0.002$ and gene ranking in the top 2\%) compared with normal tissues (Table IV). Of the 21 analyzed tumor types, 5 exhibited a correlation with downregulation of ASCL3 (Table IV).

Analysis of various renal tumor subtypes indicated that ASCL3 exhibited a lower expression in renal oncocytoma with a fold change of $-1.60, \mathrm{P}=5.15 \mathrm{E}-16$ and gene ranking in the top $3 \%$. ASCL3 expression is downregulated in cervical cancer with a fold change of $-1.65, \mathrm{P}=1.24 \mathrm{E}-9$ and gene ranking in the top $1 \%$. In superficial bladder cancer, we found that ASCL3 also exhibited a lower expression, with a fold change of -1.63 , $\mathrm{P}=1.16 \mathrm{E}-7$ and the gene ranking in the top $3 \%$. In anaplastic large-cell lymphoma, ASCL3 exhibited lower expression, with a fold change of $-1.96, \mathrm{P}=1.58 \mathrm{E}-5$ and the gene ranking in the top $8 \%$. Melanomas and basal cell skin carcinoma (also referred to as basalioma, the most common malignant skin tumor), exhibited ASCL3 downregulation with a fold change of $-1.80, \mathrm{P}=0.007$ and the gene ranking in the top $10 \%$ (Table IV). Thus, ASCL3 ranked in the top $2 \%$ of genes exhibiting upregulation in breast cancer, while in renal, cervical and bladder cancer, lymphoma and melanoma, ASCL3 displayed significant downregulation compared with normal tissues (Table IV). These findings indicated that ASCL3 may be differentially expressed in specific types of cancer and that further investigation is required to determine the mechanisms underlying the involvement of ASCL3 in tumorigenesis.

ASCL4. ASCL4 (HASH4, bHLHa44) expression is associated with skin development. ASCL4 exhibited a 7-fold higher expression in fetal skin compared with adult skin (12). The role of ASCL4 in cellular function remains elusive. Therefore, comparative genomic sequencing did not reveal any function for this gene (32). ASCL4 expression did not satisfy the selection criteria of the present study; therefore, it was not selected for further investigation.

ASCL5. We were unable to obtain any data regarding ASCL5 based on the literature search through the PubMed database. Analysis of the Gene Ontology database indicated that ASCL5 may be involved in the regulation of DNA-templated transcription (33). Our bioinformatics analysis suggested that ASCL5 was upregulated in lung cancer with a fold change of 1.96-3.71, P-values of 0.002-0.003 and the gene ranking 5-9\%. However, ASCL5 was downregulated in the majority of types of brain tumors, such as glioblastoma, anaplastic oligoastrocytoma, anaplastic oligodendroglioma and oligodendroglioma, with a fold change of -3.10 to -5.50 , P-values of 0.002-5.25E-12 and the gene ranking $1-6 \%$ (Table V). To the best of our knowledge, our bioinformatics analysis is the first report to provide any information regarding the potential role of ASCL5 in tumorigenesis.

ASCL family in clinical application. In this report, we presented an in silico analysis of the ASCL gene family and investigated the potential involvement of ASCL genes in various cancers. Our meta-analysis approach provided a conspectus of the clinical data related to the ASCL gene 
Table IV. Achaete-scute complex-like (ASCL) 3 expression in cancer.

\begin{tabular}{|c|c|c|c|c|c|c|c|c|c|}
\hline Gene & Cancer & Subtype & $\begin{array}{c}\text { Case } \\
\text { no. }\end{array}$ & $\begin{array}{l}\text { Change } \\
\text { expression }\end{array}$ & $\begin{array}{l}\text { P-value } \\
\text { (cancer/ } \\
\text { normal) }\end{array}$ & $\begin{array}{c}t \text {-test } \\
\text { (cancer/ } \\
\text { normal) }\end{array}$ & $\begin{array}{l}\text { Fold change } \\
\text { (cancer/ } \\
\text { normal) }\end{array}$ & $\begin{array}{l}\% \text { Gene } \\
\text { ranking }\end{array}$ & $\begin{array}{l}\text { Database } \\
\text { reference }\end{array}$ \\
\hline \multirow[t]{7}{*}{ ASCL3 } & Breast & $\begin{array}{l}\text { Invasive ductal } \\
\text { breast carcinoma }\end{array}$ & 30 & $\uparrow$ & 0.002 & 3.33 & 2.26 & 220 (top 2\%) & (94) \\
\hline & \multirow[t]{2}{*}{ Kidney } & Renal oncocytoma & 92 & $\downarrow$ & $5.15 \mathrm{E}-16$ & -14.47 & -1.60 & 340 (top 3\%) & $(95)$ \\
\hline & & $\begin{array}{l}\text { Clear cell renal } \\
\text { cell carcinoma }\end{array}$ & 20 & $\downarrow$ & $2.48 \mathrm{E}-4$ & -4.66 & -3.08 & 1,143 (top $10 \%$ ) & (95) \\
\hline & Cervical & Cervical cancer & 84 & $\downarrow$ & $1.24 \mathrm{E}-9$ & -8.49 & -1.65 & 96 (top 1\%) & (96) \\
\hline & Bladder & $\begin{array}{l}\text { Superficial bladder } \\
\text { cancer }\end{array}$ & 60 & $\downarrow$ & $1.16 \mathrm{E}-7$ & -6.62 & -1.63 & 274 (top 3\%) & $(75)$ \\
\hline & Lymphoma & $\begin{array}{l}\text { Anaplastic large- } \\
\text { cell lymphoma }\end{array}$ & 60 & $\downarrow$ & $1.58 \mathrm{E}-5$ & -8.87 & -1.96 & 1,547 (top 8\%) & (97) \\
\hline & Melanoma & $\begin{array}{l}\text { Skin basal cell } \\
\text { carcinoma }\end{array}$ & 87 & $\downarrow$ & 0.007 & -2.74 & -1.80 & 1,915 (top 10\%) & $(80)$ \\
\hline
\end{tabular}

Table V. Achaete-scute complex-like (ASCL) 5 expression in cancer.

\begin{tabular}{|c|c|c|c|c|c|c|c|c|c|}
\hline Gene & Cancer & Subtype & $\begin{array}{c}\text { Case } \\
\text { no. }\end{array}$ & $\begin{array}{c}\text { Change } \\
\text { expression }\end{array}$ & $\begin{array}{l}\text { P-value } \\
\text { (cancer/ } \\
\text { normal) }\end{array}$ & $\begin{array}{c}t \text {-test } \\
\text { (cancer/ } \\
\text { normal) }\end{array}$ & $\begin{array}{l}\text { Fold change } \\
\text { (cancer/ } \\
\text { normal) }\end{array}$ & $\begin{array}{l}\% \text { Gene } \\
\text { ranking }\end{array}$ & $\begin{array}{l}\text { Database } \\
\text { reference }\end{array}$ \\
\hline \multirow[t]{6}{*}{ ASCL5 } & Lung & $\begin{array}{l}\text { Small-cell lung } \\
\text { carcinoma }\end{array}$ & 73 & $\uparrow$ & 0.003 & 4.91 & 3.71 & 442 (top 5\%) & $(60)$ \\
\hline & & $\begin{array}{l}\text { Squamous cell } \\
\text { lung carcinoma }\end{array}$ & 73 & $\uparrow$ & 0.002 & 3.26 & 1.96 & 911 (top 9\%) & $(60)$ \\
\hline & Brain & Glioblastoma & 54 & $\downarrow$ & $5.25 \mathrm{E}-12$ & -11.49 & -3.10 & 141 (top $1 \%$ ) & $(52)$ \\
\hline & & $\begin{array}{l}\text { Anaplastic } \\
\text { oligoastrocytoma }\end{array}$ & 54 & $\downarrow$ & $1.57 \mathrm{E}-4$ & -7.74 & -3.79 & $322($ top 3\%) & $(52)$ \\
\hline & & $\begin{array}{l}\text { Anaplastic } \\
\text { oligodendroglioma }\end{array}$ & 54 & $\downarrow$ & $7.70 \mathrm{E}-4$ & -13.99 & -5.50 & 480 (top 4\%) & $(52)$ \\
\hline & & Oligodendroglioma & 54 & $\downarrow$ & 0.002 & -5.74 & -4.24 & 878 (top 6\%) & $(52)$ \\
\hline
\end{tabular}

family and suggested that alterations in the ASCL genes may result in development of various tumors. Moreover, our analysis utilized the integration and validation of numerous microarray datasets, thereby allowing the use of an ASCL gene with its correlated cancers and its subtypes as future biomarkers for future cancer studies.

It was previously indicated that ASCL1 functions as an oncogene in lung cancer (23). Recent findings also demonstrated that ASCL1 is a marker for small-cell lung carcinomas $(23,34)$. These data are consistent with our bioinformatics analyses (Fig. 1). ASCL1 exhibited significant overexpression in half of the analyzed cancer types (10 of 20 cancers), with the gene ranking in the top $10 \%$. Moreover, a significant number of tumors exhibited ASCL1 downregulation, with the gene ranking in the top $1 \%$ (Fig. 1). ASCL1 was in the top $1 \%$ ranking of all overexpressed genes in leukemia, brain and lung cancers. Interestingly, gastric cancers and melanoma displayed downregulation of ASCL1, with the gene ranking in the top $1 \%$ of all downregulated genes.
Previous studies have suggested that ASCL2 is strongly expressed in colon cancer tissues and cell lines (HT-29 and LS174T cells) and that selective blockade of ASCL2 results in the inhibition of xenograft tumor growth, proliferation, invasion and migration $(10,29,30)$. ASCL2 may promote colorectal (30), lung (35) and gastric cancer (36), suggesting a crucial role for ASCL2 involvement in tumor development. These data are consistent with our bioinformatics analysis (Fig. 1). Strikingly, ASCL2 expression analysis indicated increased mRNA expression in some cancer tissues and decreased expression in others. ASCL2 is in the top $10 \%$ of genes exhibiting overexpression in breast, colorectal, lung, gastric, head-neck, ovarian and testicular cancers, as well as lymphoma. However, brain tumor and melanoma subtypes exhibited significant reductions in the expression of ASCL2 when compared with normal tissues (Table III). Of note, ASCL3 expression displayed a wide range of mRNA levels in various cancers. ASCL 3 was in the top $2 \%$ of overexpressed genes in breast cancer. Conversely, in lymphomas, melanomas, 
renal, cervical and bladder cancers, ASCL3 expression was significantly reduced compared with that in normal tissues (Table IV). Expression analysis of ASCL5 suggested a correlation between elevated ASCL5 expression and lung cancer development. ASCL5 was one of highly expressed genes, ranking 5-9\% in lung cancer. Interestingly, ASCL5 was downregulated in most types of brain tumors, such as glioblastoma, anaplastic oligoastrocytoma and anaplastic oligodendroglioma. The decrease in fold change ranged from -3.10 to -5.50 , the P-values ranged from 0.002 to $5.25 \mathrm{E}-12$, with the gene ranking 1-6\% (Table V). Intriguingly, ASCL members exhibited increased expression in some cancer tissues and decreased expression in others. This is particularly apparent for ASCL2, ASCL3 and ASCL5 that displayed mRNA expression changes (either up-or downregulated in specific cancers). According to these data, both the up- and downregulation of ASCL genes may play an important role in tumor development. The emerging view of the unique developmental niche of ASCL members in early progenitors of diverse neural lineages suggests a potentially critical role in injury response, wound healing and tumorigenesis. However, a limited number of studies to date suggest that these ASCL members may contribute significantly to cancer development. The available data collectively suggest that alterations in the expression of ASCL genes may affect cellular behavior, such as cell proliferation, thereby initiating tumor development. The present study demonstrated that ASCL members may be involved in tumor development and introduces ASCL genes as potential candidates for future prognostic and therapeutic targets.

\section{Acknowledgements}

Computational analyses and data mining were performed using the system provided by the Bioinformatics Core at the National Cheng Kung University, supported by the National Science Council, Taiwan. We would also like to thank the Ministry of Science and Technology for the grants MOST103-2325-B006-012 (to MDL) and 104-2917-I-006-002 (to CYW) and the National Cancer Institute (USA) for the R01 CA180039 grant (to ZW).

\section{References}

1. Forman D, Ferlay J, Stewart B and Wild C: The global and regional burden of cancer. World cancer report 64-185, 2014.

2. Hanahan D and Weinberg RA: Hallmarks of cancer: The next generation. Cell 144: 646-674, 2011

3. Guillemot F, Lo LC, Johnson JE, Auerbach A, Anderson DJ and Joyner AL: Mammalian achaete-scute homolog-1 is required for the early development of olfactory and autonomic neurons. Cell 75: 463-476, 1993.

4. Gestblom C, Grynfeld A, Ora I, Ortoft E, Larsson C, Axelson H, Sandstedt B, Cserjesi P, Olson EN and Påhlman S: The basic helix-loop-helix transcription factor dHAND, a marker gene for the developing human sympathetic nervous system, is expressed in both high- and low-stage neuroblastomas. Lab Invest 79: 67-79, 1999.

5. Mizuguchi R, Kriks S, Cordes R, Gossler A, Ma QF and Goulding M: ASCL1 and GSH1/2 control inhibitory and excitatory cell fate in spinal sensory interneurons. Nat Neurosci 9: 770-778, 2006

6. Pattyn A, Simplicio N, van Doorninck JH, Goridis C, Guillemot F and Brunet JF: ASCL1/MASH1 is required for the development of central serotonergic neurons. Nat Neurosci 7: 589-595, 2004.
7. Ge WH, He F, Kim KJ, Blanchi B, Coskun V, Nguyen L, Wu X, Zhao J, Heng JI, Martinowich K, et al: Coupling of cell migration with neurogenesis by proneural bHLH factors. Proc Natl Acad Sci USA 103: 1319-1324, 2006.

8. Borges M, Linnoila RI, van de Velde HJ, Chen H, Nelkin BD, Mabry M, Baylin SB and Ball DW: An achaete-scute homologue essential for neuroendocrine differentiation in the lung. Nature 386: 852-855, 1997

9. Ball DW, Azzoli CG, Baylin SB, Chi D, Dou S, Donis-Keller H, Cumaraswamy A, Borges M and Nelkin BD: Identification of a human achaete-scute homolog highly expressed in neuroendocrine tumors. Proc Natl Acad Sci USA 90: 5648-5652, 1993.

10. Guillemot F, Nagy A, Auerbach A, Rossant J and Joyner AL: Essential role of MASH-2 in extraembryonic development. Nature 371: 333-336, 1994.

11. Schuijers J, Junker JP, Mokry M, Hatzis P, Koo BK, Sasselli V, van der Flier LG, Cuppen E, van Oudenaarden A and Clevers H: ASCL2 acts as an R-spondin/WNT-responsive switch to control stemness in intestinal crypts. Cell Stem Cell 16: 158-170, 2015.

12. van der Flier LG, van Gijn ME, Hatzis P, Kujala P, Haegebarth A, Stange DE, Begthel H, van den Born M, Guryev V, Oving I, et al: Transcription factor achaete scute-like 2 controls intestinal stem cell fate. Cell 136: 903-912, 2009.

13. Tian Y, Pan Q, Shang Y, Zhu R, Ye J, Liu Y, Zhong X, Li S, He Y, Chen L, et al: MicroRNA-200 (miR-200) cluster regulation by achaete scute-like 2 (ASCL2): Impact on the epithelial-mesenchymal transition in colon cancer cells. J Biol Chem 289: 36101-36115, 2014.

14. Rugel-Stahl A, Elliott ME and Ovitt CE: Ascl3 marks adult progenitor cells of the mouse salivary gland. Stem Cell Res 8: 379-387, 2012.

15. Jonsson M, Björntorp Mark E, Brantsing C, Brandner JM, Lindahl A and Asp J: HASH4, a novel human achaete-scute homologue found in fetal skin. Genomics 84: 859-866, 2004.

16. Rhodes DR, Kalyana-Sundaram S, Mahavisno V, Varambally R, Yu J, Briggs BB, Barrette TR, Anstet MJ, Kincead-Beal C, Kulkarni P, et al: Oncomine 3.0: Genes, pathways, and networks in a collection of 18,000 cancer gene expression profiles. Neoplasia 9: 166-180, 2007.

17. Ewald JA, Downs TM, Cetnar JP and Ricke WA: Expression microarray meta-analysis identifies genes associated with Ras/MAPK and related pathways in progression of muscle-invasive bladder transition cell carcinoma. PLoS One 8: e55414, 2013.

18. Moher D, Liberati A, Tetzlaff J and Altman DG; PRISMA Group: Preferred reporting items for systematic reviews and meta-analyses: The PRISMA statement. BMJ 339: b2535, 2009.

19. Rhodes DR and Chinnaiyan AM: Integrative analysis of the cancer transcriptome. Nat Genet 37: S31-S37, 2005.

20. Rhodes DR, Yu JJ, Shanker K, Deshpande N, Varambally R, Ghosh D, Barrette T, Pandey A and Chinnaiyan AM: ONCOMINE: A cancer microarray database and integrated data-mining platform. Neoplasia 6: 1-6, 2004.

21. Casarosa S, Fode C and Guillemot F: MASH1 regulates neurogenesis in the ventral telencephalon. Development 126: 525-534, 1999.

22. Pacary E, Heng JL, Azzarelli R, Riou P, Castro D, Lebel-Potter M, Parras C, Bell DM, Ridley AJ, Parsons M and Guillemot F: Proneural transcription factors regulate different steps of cortical neuron migration through Rnd-mediated inhibition of RhoA signaling. Neuron 69: 1069-1084, 2011.

23. Augustyn A, Borromeo M, Wang T, Fujimoto J, Shao C, Dospoy PD, Lee V, Tan C, Sullivan JP, Larsen JE, et al: ASCL1 is a lineage oncogene providing therapeutic targets for high-grade neuroendocrine lung cancers. Proc Natl Acad Sci USA 111: 14788-14793, 2014

24. Martino-Echarri E, Fernández-Rodríguez R, Rodríguez-Baena FJ, Barrientos-Durán A, Torres-Collado AX, Plaza-Calonge Mdel C, Amador-Cubero S, Cortés J, Reynolds LE, Hodivala-Dilke KM, et al: Contribution of ADAMTS1 as a tumor suppressor gene in human breast carcinoma. Linking its tumor inhibitory properties to its proteolytic activity on nidogen-1 and nidogen-2. Int J Cancer 133: 2315-2324, 2013

25. Kim HS, Patel K, Muldoon-Jacobs K, Bisht KS, Aykin-Burns N, Pennington JD, van der Meer R, Nguyen P, Savage J, Owens KM, et al: SIRT3 is a mitochondria-localized tumor suppressor required for maintenance of mitochondrial integrity and metabolism during stress. Cancer Cell 17: 41-52, 2010.

26. Johnson JE, Birren SJ and Anderson DJ: Two rat homologues of drosophila achaete-scute specifically expressed in neuronal precursors. Nature 346: 858-861, 1990. 
27. Yan KS and Kuo CJ: ASCL2 reinforces intestinal stem cell identity. Cell Stem Cell 16: 105-106, 2015.

28. Liu XD, Chen X, Zhong B, Wang A, Wang X, Chu F, Nurieva RI, Yan X, Chen P, van der Flier LG, et al: Transcription factor achaete-scute homologue 2 initiates follicular T-helper-cell development. Nature 507: 513-518, 2014.

29. Zhu R, Yang YT, Tian Y, Bai J, Zhang X, Li X, Peng Z, He Y, Chen L, Pan Q, et al: ASCL2 knockdown results in tumor growth arrest by miRNAs-302b-related inhibition of colon cancer progenitor cells. Plos One 7: e32170, 2012.

30. Ziskin JL, Dunlap D, Yaylaoglu M, Fodor IK, Forrest WF, Patel R, Ge N, Hutchins GG, Pine JK, Quirke P, et al: In situ validation of an intestinal stem cell signature in colorectal cancer. Gut 62: 1012-1023, 2013

31. Bullard T, Koek L, Roztocil E, Kingsley PD, Mirels L and Ovitt CE: ASCL3 expression marks a progenitor population of both acinar and ductal cells in mouse salivary glands. Dev Biol 320: 72-78, 2008

32. Amid C, Bahr A, Mujica A, Sampson N, Bikar SE, Winterpacht A, Zabel B, Hankeln T and Schmidt ER: Comparative genomic sequencing reveals a strikingly similar architecture of a conserved syntenic region on human chromosome $11 \mathrm{p} 15.3$ (including gene ST5) and mouse chromosome 7. Cytogenet Cell Genet 93: 284-290, 2001

33. Ashburner M, Ball CA, Blake JA, Botstein D, Butler H, Cherry JM, Davis AP, Dolinski K, Dwight SS, Eppig JT, et al: Gene Ontology: Tool for the unification of biology. The Gene Ontology Consortium. Nat Genet 25: 25-29, 2000.

34. Lenhart R, Kirov S, Desilva H, Cao J, Lei M, Johnston K, Peterson R, Schweizer L, Purandare A, Ross-Macdonald P, et al: Sensitivity of small cell lung cancer to BET inhibition is mediated by regulation of ASCL1 gene expression. Mol Cancer Ther 14: $2167-2174,2015$

35. Hu XG, Chen L, Wang QL, Zhao XL, Tan J, Cui YH, Liu XD, Zhang X and Bian XW: Elevated expression of ASCL2 is an independent prognostic indicator in lung squamous cell carcinoma. J Clin Pathol 69: 313-318, 2016.

36. Sureban SM, Qu D and Houchen CW: Regulation of miRNAs by agents targeting the tumor stem cell markers DCLK1, MSI1, LGR5, and BMI1. Curr Pharmacol Rep 1: 217-222, 2015.

37. López-Carballo G, Moreno L, Masia S, Pérez P and Barettino D Activation of the phosphatidylinositol 3-kinase/Akt signaling pathway by retinoic acid is required for neural differentiation of SH-SY5Y human neuroblastoma cells. J Biol Chem 277: 25297-25304, 2002

38. Letinic K, Zoncu R and Rakic P: Origin of GABAergic neurons in the human neocortex. Nature 417: 645-649, 2002.

39. Persson P, Jögi A, Grynfeld A, Påhlman S and Axelson H: HASH-1 and E2-2 are expressed in human neuroblastoma cells and form a functional complex. Biochem Biophys Res Commun 274: 22-31, 2000.

40. Wang XY, Dakir el H, Naizhen X, Jensen-Taubman SM, DeMayo FJ and Linnoila RI: Achaete-scute homolog-1 linked to remodeling and preneoplasia of pulmonary epithelium. Lab Invest 87: 527-539, 2007.

41. de Pontual L, Népote V, Attié-Bitach T, Al Halabiah H, Trang H, Elghouzzi V, Levacher B, Benihoud K, Augé J, Faure C, et al: Noradrenergic neuronal development is impaired by mutation of the proneural HASH-1 gene in congenital central hypoventilation syndrome (Ondine's curse). Hum Mol Genet 12: 3173-3180, 2003

42. Ito $\mathrm{T}$, Udaka $\mathrm{N}$, Okudela $\mathrm{K}$, Yazawa $\mathrm{T}$ and Kitamura $\mathrm{H}$ : Mechanisms of neuroendocrine differentiation in pulmonary neuroendocrine cells and small cell carcinoma. Endocr Pathol 14: 133-139, 2003

43. Kunnimalaiyaan $\mathrm{M}$, Traeger $\mathrm{K}$ and Chen $\mathrm{H}$ : Conservation of the NOTCH1 signaling pathway in gastrointestinal carcinoid cells. Am J Physiol Gastrointest Liver Physiol 289: G636-G642, 2005.

44. Kim HJ, McMillan E, Han F and Svendsen CN: Regionally specified human neural progenitor cells derived from the mesencephalon and forebrain undergo increased neurogenesis following overexpression of ASCL1. Stem cells 27: 390-398, 2009.

45. Nakayama H, Scott IC and Cross JC: The transition to endoreduplication in trophoblast giant cells is regulated by the mSNA zinc finger transcription factor. Dev Biol 199: 150-163, 1998

46. Nishiyama A, Xin L, Sharov AA, Thomas M, Mowrer G, Meyers E, Piao Y, Mehta S, Yee S, Nakatake Y, et al: Uncovering early response of gene regulatory networks in ESCs by systematic induction of transcription factors. Cell Stem Cell 5: 420-433, 2009.
47. Tanaka M, Gertsenstein M, Rossant J and Nagy A: Mash2 acts cell autonomously in mouse spongiotrophoblast development. Dev Biol 190: 55-65, 1997.

48. Oh-McGinnis R, Bogutz AB and Lefebvre L: Partial loss of ASCL2 function affects all three layers of the mature placenta and causes intrauterine growth restriction. Dev Biol 351: 277-286, 2011.

49. Yoshida S, Ohbo K, Takakura A, Takebayashi H, Okada T, Abe K and Nabeshima Y: SGN1, a basic helix-loop-helix transcription factor delineates the salivary gland duct cell lineage in mice. Dev Biol 240: 517-530, 2001

50. Rolland T, Tasan M, Charloteaux B, Pevzner SJ, Zhong Q, Sahni N, Yi S, Lemmens I, Fontanillo C, Mosca R, et al: A proteome-scale map of the human interactome network. Cell 159: 1212-1226, 2014

51. Sun LX, Hui AM, Su Q, Vortmeyer A, Kotliarov Y, Pastorino S, Passaniti A, Menon J, Walling J, Bailey R, et al: Neuronal and glioma-derived stem cell factor induces angiogenesis within the brain. Cancer Cell 9: 287-300, 2006.

52. Bredel M, Bredel C, Juric D, Harsh GR, Vogel H, Recht LD and Sikic BI: Functional network analysis reveals extended gliomagenesis pathway maps and three novel MYC-interacting genes in human gliomas. Cancer Res 65: 8679-8689, 2005.

53. Liang Y, Diehn M, Watson N, Bollen AW, Aldape KD, Nicholas MK, Lamborn KR, Berger MS, Botstein D, Brown PO and Israel MA: Gene expression profiling reveals molecularly and clinically distinct subtypes of glioblastoma multiforme. Proc Natl Acad Sci USA 102: 5814-5819, 2005.

54. Lee J, Kotliarova S, Kotliarov Y, Li A, Su Q, Donin NM, Pastorino S, Purow BW, Christopher N, Zhang W, et al: Tumor stem cells derived from glioblastomas cultured in bFGF and EGF more closely mirror the phenotype and genotype of primary tumors than do serum-cultured cell lines. Cancer Cell 9: 391-403, 2006.

55. Murat A,MigliavaccaE,GorliaT,Lambiv WL, Shay T,Hamou MF, de Tribolet N, Regli L, Wick W, Kouwenhoven MC, et al: Stem cell-related 'self-renewal' signature and high epidermal growth factor receptor expression associated with resistance to concomitant chemoradiotherapy in glioblastoma. J Clin Oncol 26: 3015-3024, 2008

56. French PJ, Swagemakers SM, Nagel JH, Kouwenhoven MC, Brouwer E, van der Spek P, Luider TM, Kros JM, van den Bent MJ and Sillevis Smitt PA: Gene expression profiles associated with treatment response in oligodendrogliomas. Cancer Res 65: 11335-11344, 2005.

57. Cancer Genome Atlas Research Network: Comprehensive genomic characterization defines human glioblastoma genes and core pathways. Nature 455: 1061-1068, 2008.

58. Shai R, Shi T, Kremen TJ, Horvath S, Liau LM, Cloughesy TF, Mischel PS and Nelson SF: Gene expression profiling identifies molecular subtypes of gliomas. Oncogene 22: 4918-4923, 2003.

59. Bhattacharjee A, Richards WG, Staunton J, Li C, Monti S, Vasa P, Ladd C, Beheshti J, Bueno R, Gillette M, et al: Classification of human lung carcinomas by mRNA expression profiling reveals distinct adenocarcinoma subclasses. Proc Natl Acad Sci USA 98: 13790-13795, 2001.

60. Garber ME, Troyanskaya OG, Schluens K, Petersen S, Thaesler Z, Pacyna-Gengelbach M, van de Rijn M, Rosen GD, Perou CM, Whyte RI, et al: Diversity of gene expression in adenocarcinoma of the lung. Proc Natl Acad Sci USA 98: 13784-13789, 2001.

61. Choi YL, Tsukasaki K, O'Neill MC, Yamada Y, Onimaru Y, Matsumoto K, Ohashi J, Yamashita Y, Tsutsumi S, Kaneda R, et al: A genomic analysis of adult T-cell leukemia. Oncogene 26: 1245-1255, 2007.

62. Zhan FH, Barlogie B, Arzoumanian V, Huang Y, Williams DR, Hollmig K, Pineda-Roman M, Tricot G, van Rhee F, Zangari M, et al: A gene expression signature of benign monoclonal gammopathy evident in multiple myeloma is linked to good prognosis. Blood 109: 1692-1700, 2006.

63. Basso K, Margolin AA, Stolovitzky G, Klein U, Dalla-Favera R and Califano A: Reverse engineering of regulatory networks in human B cells. Nat Genet 37: 382-390, 2005.

64. Frierson HF Jr, El-Naggar AK, Welsh JB, Sapinoso LM, Su AI, Cheng J, Saku T, Moskaluk CA and Hampton GM: Large scale molecular analysis identifies genes with altered expression in salivary adenoid cystic carcinoma. Am J Pathol 161: 1315-1323, 2002.

65. Detwiller KY, Fernando NT, Segal NH, Ryeom SW, D'Amore PA and Yoon SS: Analysis of hypoxia-related gene expression in sarcomas and effect of hypoxia on RNA interference of vascular endothelial cell growth factor A. Cancer Res 65: 5881-5889, 2005. 
66. Cho JY, Lim JY, Cheong JH, Park YY, Yoon SL, Kim SM, Kim SB, Kim H, Hong SW, Park YN, et al: Gene expression signature-based prognostic risk score in gastric cancer. Clin Cancer Res 17: 1850-1857, 2011

67. LaTulippe E, Satagopan J, Smith A, Scher H, Scardino P, Reuter V and Gerald WL: Comprehensive gene expression analysis of prostate cancer reveals distinct transcriptional programs associated with metastatic disease. Cancer Res 62: 4499-4506, 2002.

68. Grasso CS, Wu YM, Robinson DR, Cao X, Dhanasekaran SM Khan AP, Quist MJ, Jing X, Lonigro RJ, Brenner JC, et al: The mutational landscape of lethal castration-resistant prostate cancer. Nature 487: 239-243, 2012.

69. Iacobuzio-Donahue CA, Maitra A, Olsen M, Lowe AW, van Heek NT, Rosty C, Walter K, Sato N, Parker A, Ashfaq R, et al: Exploration of global gene expression patterns in pancreatic adenocarcinoma using cDNA microarrays. Am J Pathol 162: 1151-1162, 2003.

70. Yusenko MV, Kuiper RP, Boethe T, Ljungberg B, van Kessel AG and Kovacs G: High-resolution DNA copy number and gene expression analyses distinguish chromophobe renal cell carcinomas and renal oncocytomas. BMC Cancer 9: 152, 2009.

71. Hao Y, Triadafilopoulos G, Sahbaie P, Young HS, Omary MB and Lowe AW: Gene expression profiling reveals stromal genes expressed in common between Barrett's esophagus and adenocarcinoma. Gastroenterology 131: 925-933, 2006.

72. D'Errico M, de Rinaldis E, Blasi MF, Viti V, Falchetti M, Calcagnile A, Sera F, Saieva C, Ottini L, Palli D, et al: Genome-wide expression profile of sporadic gastric cancers with microsatellite instability. Eur J Cancer 45: 461-469, 2009

73. Wang Q, Wen YG, Li DP, Xia J, Zhou CZ, Yan DW, Tang HM and Peng ZH: Upregulated INHBA expression is associated with poor survival in gastric cancer. Med Oncol 29: 77-83, 2012.

74. Cui JA, Chen YB, Chou WC, Sun L, Chen L, Suo J, Ni Z, Zhang M, Kong X, Hoffman LL, et al: An integrated transcriptomic and computational analysis for biomarker identification in gastric cancer. Nucleic Acids Res 39: 1197-1207, 2011.

75. Dyrskjøt L, Kruhøffer M, Thykjaer T, Marcussen N, Jensen JL, Møller K and Ørntoft TF: Gene expression in the urinary bladder: A common carcinoma in situ gene expression signature exists disregarding histopathological classification. Cancer Res 64: 4040-4048, 2004

76. Zhao H, Langerød A, Ji Y, Nowels KW, Nesland JM, Tibshirani R, Bukholm IK, Kåresen R, Botstein D, Børresen-Dale AL and Jeffrey SS: Different gene expression patterns in invasive lobular and ductal carcinomas of the breast. Mol Biol Cell 15: 2523-2536, 2004.

77. Sabates-Bellver J, Van der Flier LG, de Palo M, Cattaneo E, Maake C, Rehrauer H, Laczko E, Kurowski MA, Bujnicki JM, Menigatti M, et al: Transcriptome profile of human colorectal adenomas. Mol Cancer Res 5: 1263-1275, 2007.

78. Haqq C, Nosrati M, Sudilovsky D, Crothers J, Khodabakhsh D, Pulliam BL, Federman S, Miller JR III, Allen RE, Singer MI, et al: The gene expression signatures of melanoma progression. Proc Natl Acad Sci USA 102: 6092-6097, 2005.

79. Talantov D, Mazumder A, Yu JX, Briggs T, Jiang Y, Backus J, Atkins D and Wang Y: Novel genes associated with malignant melanoma but not benign melanocytic lesions. Clin Cancer Res 11: 7234-7242, 2005.

80. Riker AI, Enkemann SA, Fodstad O, Liu S, Ren S, Morris C, Xi Y, Howell P, Metge B, Samant RS, et al: The gene expression profiles of primary and metastatic melanoma yields a transition point of tumor progression and metastasis. Bmc Med Genomics 1: 13, 2008.

81. Curtis C, Shah SP, Chin SF, Turashvili G, Rueda OM, Dunning MJ, Speed D, Lynch AG, Samarajiwa S, Yuan Y, et al: The genomic and transcriptomic architecture of 2,000 breast tumours reveals novel subgroups. Nature 486: 346-352, 2012

82. Finak G, Bertos N, Pepin F, Sadekova S, Souleimanova M, Zhao H, Chen H, Omeroglu G, Meterissian S, Omeroglu A, et al: Stromal gene expression predicts clinical outcome in breast cancer. Nat Med 14: 518-527, 2008.

83. Radvanyi L, Singh-Sandhu D, Gallichan S, Lovitt C, Pedyczak A Mallo G, Gish K, Kwok K, Hanna W, Zubovits J, et al: The gene associated with trichorhinophalangeal syndrome in humans is overexpressed in breast cancer. Proc Natl Acad Sci USA 102: 11005-11010, 2005.
84. Gaedcke J, Grade M, Jung K, Camps J, Jo P, Emons G, Gehoff A, Sax U, Schirmer M, Becker H, et al: Mutated KRAS results in overexpression of DUSP4, a MAP-kinase phosphatase and SMYD3, a histone methyltransferase, in rectal carcinomas. Genes Chrom Cancer 49: 1024-1034, 2010.

85. Kaiser S, Park YK, Franklin JL, Halberg RB, Yu M, Jessen WJ, Freudenberg J, Chen X, Haigis K, Jegga AG, et al: Transcriptional recapitulation and subversion of embryonic colon development by mouse colon tumor models and human colon cancer. Genome Biol 8: R131, 2007.

86. Hong Y, Downey T, Eu KW, Koh PK and Cheah PY: A 'metastasis-prone' signature for early-stage mismatch-repair proficient sporadic colorectal cancer patients and its implications for possible therapeutics. Clin Exp Metastasis 27: 83-90, 2010.

87. Skrzypczak M, Goryca K, Rubel T, Paziewska A, Mikula M, Jarosz D, Pachlewski J, Oledzki J and Ostrowski J: Modeling oncogenic signaling in colon tumors by multidirectional analyses of microarray data directed for maximization of analytical reliability. PLoS One 5: e13091, 2010.

88. Hou J, Aerts J, den Hamer B, van Ijcken W, den Bakker M, Riegman P, van der Leest C, van der Spek P, Foekens JA, Hoogsteden HC, et al: Gene expression-based classification of non-small cell lung carcinomas and survival prediction. Plos One 5: e10312, 2010.

89. Brune V, Tiacci E, Pfeil I, Döring C, Eckerle S, van Noesel CJ, Klapper W, Falini B, von Heydebreck A, Metzler D, et al: Origin and pathogenesis of nodular lymphocyte-predominant Hodgkin lymphoma as revealed by global gene expression analysis. J Exp Med 205: 2251-2268, 2008.

90. Sengupta S, den Boon JA, Chen IH, Newton MA, Dahl DB, Chen M, Cheng YJ, Westra WH, Chen CJ, Hildesheim A, et al: Genome-wide expression profiling reveals EBV-associated inhibition of MHC class I expression in nasopharyngeal carcinoma. Cancer Res 66: 7999-8006, 2006.

91. Lu KH, Patterson AP, Wang L, Marquez RT, Atkinson EN, Baggerly KA, Ramoth LR, Rosen DG, Liu J, Hellstrom I, et al: Selection of potential markers for epithelial ovarian cancer with gene expression arrays and recursive descent partition analysis. Clin Cancer Res 10: 3291-3300, 2004

92. Skotheim RI, Lind GE, Monni O, Nesland JM, Abeler VM, Fosså SD, Duale N, Brunborg G, Kallioniemi O, Andrews PW and Lothe RA: Differentiation of human embryonal carcinomas in vitro and in vivo reveals expression profiles relevant to normal development. Cancer Res 65: 5588-5598, 2005.

93. Arredouani MS, Lu B, Bhasin M, Eljanne M, Yue W, Mosquera JM, Bubley GJ, Li V, Rubin MA, Libermann TA and Sanda MG: Identification of the transcription factor single-minded homologue 2 as a potential biomarker and immunotherapy target in prostate cancer. Clin Cancer Res 15: 5794-5802, 2009.

94. Turashvili G, Bouchal J, Baumforth K, Wei W, Dziechciarkova M, Ehrmann J, Klein J, Fridman E, Skarda J, Srovnal J, et al: Novel markers for differentiation of lobular and ductal invasive breast carcinomas by laser microdissection and microarray analysis. BMC Cancer 7: 55, 2007.

95. Jones J, Otu H, Spentzos D, Kolia S, Inan M, Beecken WD, Fellbaum C, Gu X, Joseph M, Pantuck AJ, et al: Gene signatures of progression and metastasis in renal cell cancer. Clin Cancer Res 11: 5730-5739, 2005.

96. Pyeon D, Newton NA, Lambert PF, den Boon JA, Sengupta S, Marsit CJ, Woodworth CD, Connor JP, Haugen TH, Smith EM, et al: Fundamental differences in cell cycle deregulation in human papillomavirus-positive and human papillomavirus-negative head/neck and cervical cancers. Cancer Res 67: 4605-4619,2007.

97. Piccaluga PP, Agostinelli C, Califano A, Rossi M, Basso K, Zupo S, Went P, Klein U, Zinzani PL, Baccarani M, et al: Gene expression analysis of peripheral $\mathrm{T}$ cell lymphoma, unspecified, reveals distinct profiles and new potential therapeutic targets. J Clin Invest 117: 823-834, 2007.

98. Cancer Genome Atlas Network: Comprehensive molecular characterization of human colon and rectal cancer. Nature 487: 330-337, 2012. 